\title{
Endotoxin-induced interruption of early pregnancy in the rabbit
}

\author{
G. Valenzuela, M. J. K. Harper and L. Magnasco
}

Center for Research and Training in Reproductive Biology, Department of Obstetrics and Gynecology, The University of Texas Health Science Center at San Antonio, 7703 Floyd Curl Drive, San Antonio, Texas 78284, U.S.A.

\begin{abstract}
Summary. Endotoxin derived from Salmonella enteritidis (Boivin) completely interrupted pregnancy in the rabbit when given as a single dose (10 or $20 \mu \mathrm{g} / \mathrm{kg})$ intravenously on Day 4 or Day 8 of pregnancy. Indomethacin $(2$ or $10 \mathrm{mg} / \mathrm{kg}$ ) was unable to prevent this effect.
\end{abstract}

\section{Introduction}

Endotoxin from Salmonella enteritidis has been shown to induce abortion and fetal death in mice when given intravenously on Day 16 of pregnancy (Skarnes \& Harper, 1972; Harper \& Skarnes, 1972). Abortion and diarrhoea, but not fetal death in utero, caused by endotoxin were prevented by pretreatment with $2 \mathrm{mg}$ indomethacin/kg subcutaneously (Skarnes \& Harper, 1972; Harper \& Skarnes, 1972). Indomethacin is a potent inhibitor of prostaglandin (PG) synthesis (Vane, 1971 ; Ferreira, Moncada \& Vane, 1971). Endotoxin also causes acceleration of ovum transport when given $(10 \mu \mathrm{g} / \mathrm{kg}$ i.v.) to rabbits $24 \mathrm{~h}$ after injection of hCG to induce ovulation; $>69 \%$ of the ova have left the oviduct within $4 \mathrm{~h}$ of (Harper, Valenzuela \& Hogdson, 1978) and $>87 \%$ by $24 \mathrm{~h}$ after (Valenzuela, Hodgson \& Harper, 1978) the endotoxin injection. This acceleration can be prevented by a single concurrent intramuscular administration of $10 \mathrm{mg}$ indomethacin $/ \mathrm{kg}$ (Valenzuela et al., 1978) which prevents the rise in uterine vein levels of PGF and PGE caused by endotoxin (Harper et al., 1978).

Other authors have also reported that experimental endotoxaemia can lead to abortion and fetal death in mice (Zahl \& Bjerknes, 1943; Rieder \& Thomas, 1960; Chedid, Boyer \& Parant, 1962) and women (Lynch, 1901 ; Sanarelli, 1924; Kass, 1960).

A drug that reliably accelerated ovum transport through the oviduct and caused premature entry of ova into the uterus could be a useful contraceptive, and in view of the action of endotoxin in late pregnancy, the present work was an investigation of its effect in early pregnancy.

\section{Materials and Methods}

Mature female New Zealand White rabbits $(>3.5 \mathrm{~kg}$ ) were caged individually for 30 days before being injected i.v. with 100 i.u. hCG (APL: Ayerst) and artificially inseminated with half the ejaculate from a fertile buck (Day 0). Endotoxin (Salmonella enteritidis-Boivin: Sigma Chemical Co.) was injected intravenously into the marginal ear vein on Day 4 or Day 8 of pregnancy. Indomethacin $(2 \mathrm{or} 10 \mathrm{mg} / \mathrm{kg}$ i.m.: generously donated by Merck, Sharp \& Dohme) was given concurrently with the endotoxin and again $4 \mathrm{~h}$ later to some groups of rabbits. All animals were killed on Day 14 of pregnancy by an overdose of pentobarbitone sodium. The uteri were opened and examined for the presence of fetuses and placentas. Counts were made of the number of corpora lutea, but because endotoxin alone caused marked luteal regression by Day 14, such counts were not felt to be reliable and have not been included. 


\section{Results and Discussion}

Endotoxin at a dose of $20 \mu \mathrm{g} / \mathrm{kg}$ given on Day 4 completely terminated pregnancy, since no sign of implantation swellings was seen on Day 14 (Table 1). From our previous experiments (Valenzuela et al., 1978; Harper et al., 1978), we infer that the ova were expelled from the uterus by the elevated endogenous prostaglandin levels. When endotoxin was given on Day 8 at a time when implantation was already established, a dose of $20 \mu \mathrm{g} / \mathrm{kg}$ was toxic to the mother, while a dose of $10 \mu \mathrm{g} / \mathrm{kg}$ was fully effective in terminating pregnancy and, by Day 14 , only placental remnants were observed. These results are consistent with those obtained by Chang \& Hunt (1972) who injected rabbits with $5 \mathrm{mg}$ PGF- $2 \alpha / \mathrm{kg}$ s.c. on Days 3-7 of pregnancy and recorded reduced numbers of corpora lutea, inhibition of implantation and complete failure of embryonic development. A single injection of the same dose on Day 4 of pregnancy had little effect, but metabolism of PGF-2 $\alpha$ in vivo is rapid. Furthermore,

Table 1. Effect of endotoxin on early pregnancy in the rabbit

\begin{tabular}{|c|c|c|}
\hline Treatment & $\begin{array}{l}\text { No. of } \\
\text { rabbits }\end{array}$ & $\begin{array}{c}\text { No. of fetuses } \\
\text { per rabbit }\end{array}$ \\
\hline Control (untreated) & $10 \dagger$ & $7 \cdot 5 \pm 1 \cdot 0$ \\
\hline Endotoxin $(20 \mu \mathrm{g} / \mathrm{kg}$ i.v. $)$ on Day 4 & 4 & 0 \\
\hline \multicolumn{3}{|l|}{ Endotoxin $(20 \mu \mathrm{g} / \mathrm{kg}$ i.v. $)$ on Day 4} \\
\hline + Indomethacin ( $2 \mathrm{mg} / \mathrm{kg}$ i.m.) on Day 4 & 4 & $0^{*}$ \\
\hline + Indomethacin (10 mg/kg i.m.) on Day 4 & 4 & $0^{*}$ \\
\hline Endotoxin $(10 \mu \mathrm{g} / \mathrm{kg}$ i.v.) on Day 8 & 4 & $0^{*}$ \\
\hline \multicolumn{3}{|l|}{ Endotoxin $(10 \mu \mathrm{g} / \mathrm{kg} \mathrm{i} . \mathrm{v}$.$) on Day 8$} \\
\hline + Indomethacin ( $2 \mathrm{mg} / \mathrm{kg}$ i.m.) on Day 8 & 4 & $0^{*}$ \\
\hline + Indomethacin $(10 \mathrm{mg} / \mathrm{kg}$ i.m.) on Day 8 & 4 & $0^{*}$ \\
\hline
\end{tabular}

* Placentas in various stages of degeneration, but no fetuses were observed.

$\dagger$ All control animals were pregnant.

endotoxin causes uterine yein concentrations of PGF and PGE to rise and to remain elevated for up to $9 \mathrm{~h}$. The corpora lutea are regressing, and so the endotoxin might be acting through a luteolytic mechanism, but stimulation of mechanical activity of the uterus, thus disrupting early blastocyst attachment, is also possible. We cannot distinguish between these possibilities with the present data. Indomethacin was unable to counteract the effect fully, although in animals given endotoxin and indomethacin on Day 4 of pregnancy some degenerating placentas were observed at autopsy, indicating a partial reversal of the endotoxin effect because no implantation occurred with endotoxin alone.

It is known that indomethacin alone $(8 \mathrm{mg} / \mathrm{kg} /$ day subcutaneously) given to rabbits from the day of mating causes death of the fetuses after implantation (O'Grady, Caldwell, Auletta \& Speroff, 1972) and the same dose twice daily on Days 4-7 was almost equally effective (Hoffman, 1978). Similarly, while a subcutaneous daily dose of $3 \mathrm{mg}$ indomethacin $/ \mathrm{kg}$ could reverse the antifertility effect of an intrauterine device in rabbits, doses of 2 or $6 \mathrm{mg} / \mathrm{kg} /$ day were without effect (Saksena \& Harper, 1974). The effect of indomethacin before implantation may therefore be dose dependent while after implantation is itself toxic to the fetuses. Since indomethacin at the doses and schedules used in the present study prevents death from endotoxic shock in rabbits (unpublished data), reverses the effect of endotoxin on ovum transport (Valenzuela et al., 1978; Harper et al., 1978) and abortion (Skarnes \& Harper 1972; Harper \& Skarnes, 1972) and permits some implantation (present experiments), we assume that full reversal of the endotoxin action is not achieved because of the toxic action of indomethacin on fetal and placental development. While there are unpleasant side effects associated with endotoxin administration (Griesman \& Hornick, 1973), they are usually short-lived and no worse than those following stilboestrol or ethinyl oestradiol administration lasting several days (Kuchera, 1974; 
Haspels, 1976). Furthermore, endotoxin apparently affects all stages of early pregnancy in rabbits, while in women oestrogens are effective only during the time of ovum transport through the oviduct. The lipid portion of the endotoxin molecule seems to possess most of the biological activity (Lüderitz et al., 1973) but whether side effects and contraceptive activity are exhibited by the same portions of the molecule remain to be determined.

Supported in part by the Rockefeller Foundation (Postdoctoral Fellowship to L.M.) and WHO contract (S77121).

\section{References}

Chang, M.C. \& Hunt, D.M. (1972) Effect of prostaglandin $F_{2 \alpha}$ on the early pregnancy of rabbits. Nature, Lond. 236, 120-121.

Chedid, L., Boyer, F. \& Parant, M. (1962) Etude de l'action abortive des endotoxines injectées à la souris gravide normale, castrée ou hypophysectomisée. Annls Inst. Pasteur 102, 77-84.

Ferreira, S.H., Moncada, S. \& Vane, J.R. (1971) Indomethacin and aspirin abolish prostaglandin release from the spleen. Nature, New Biol. 321, 237239.

Greisman, S.E. \& Hornick, R.B. (1973) Mechanisms of endotoxin tolerance with special reference to man. J. Infect. Dis. 128, Suppl. S265-276.

HaRPER, M.J.K. \& SKarNes, R.C. (1972) Inhibition of abortion and fetal death produced by endotoxin or prostaglandin $\mathrm{F}_{2 \alpha}$. Prostaglandins 2, 295-300.

Harper, M.J.K., Valenzuela, G. \& Hodgson, B.J. (1978) Accelerated ovum transport in rabbits induced by endotoxin. I. Changes in prostaglandin levels and reversal of endotoxin effect. Prostaglandins 15, 43-63.

HASpels, A.A. (1976) Interception: post-coital estrogens in 3016 women. Contraception 14, 375-381.

Hofrman, L.H. (1978) Antifertility effects of indomethacin during early pregnancy in the rabbit. Biol. Reprod. 18, 148-153.

KASS, E.H. (1960) Hormones and host resistance to infection. Bacteriol. Rev. 24, 177-185.

KucherA, L. (1974) Postcoital contraception with diethylstilbestrol-updated. Contraception 10, 47-54.

Lüderitz, O., Galanos, C., Lehmann, V., Nurminen, M., Rietschel, E.T., Rosenfelder, G., Simon, M. \& WESTPHAL, O. (1973) Lipid A : chemical structure and biological activity. J. Infect. Dis. 128, Suppl. S17-S29.

LYNCH, F.W. (1901) Fetal transmission of typhoid: 2 cases of the interruption of pregnancy. J. Am. Med. Ass. 36, 1136.

O'Grady, J.P., Caldwell, B.V., Auletta, F.J. \& SPEROFF, L. (1972) The effects of an inhibitor of prostaglandin synthesis (indomethacin) on ovulation, pregnancy and pseudopregnancy in the rabbit. Prostaglandins 1, 97-106.

Rieder, R.F. \& Thomas, L. (1960) Studies on the mechanisms involved in the production of abortion by endotoxin. J. Immunol. 84, 189-193.

Saksena, S.K. \& HarPer, M.J.K. (1974) Prostaglandinmediated action of intrauterine devices: F-prostaglandins in the uterine horns of pregnant rabbits with unilateral intrauterine devices. Fert. Steril. 25, 121126.

Sanarelli, G. (1924) De la pathogenie du cholera experimentelle. Annls Inst. Pasteur 28, 11-72.

Skarnes, R.C. \& HaRPER, M.J.K. (1972) The relationship between endotoxin-induced abortion and the synthesis of prostaglandin F. Prostaglandins 1, 191205.

Valenzuela, G., Hodgson, B.J. \& Harper, M.J.K. (1978) Endotoxin-induced acceleration of ovum transport in rabbits. Experientia 34, 388-389.

VANE, J.R. (1971) Inhibition of prostaglandin synthesis as a mechanism of action for aspirin-like drugs. Nature, New Biol. 321, 232-235.

ZAHL, P.A. \& BJERKNES, C. (1943) Induction of deciduaplacental hemorrhage in mice by endotoxins of certain gram-negative bacteria. Proc. Soc. exp. Biol. Med. 54, 329-332. 